\title{
The effects of an integrative supply chain strategy on customer service and firm performance: an analysis of direct versus indirect relationships
}

\author{
Zakir Sabara $^{\mathrm{a}^{*}}$, Soemarno Soemarno ${ }^{\mathrm{b}}$, Amin Setyo Leksono ${ }^{\mathrm{c}}$ and Andi Tamsil ${ }^{\mathrm{d}}$
}

${ }^{a}$ Doctoral Program of Environmental Science, Universitas Brawijaya, Malang, Indonesia

${ }^{b}$ Department of Soil Science, Faculty of Agriculture, Universitas Brawijaya, Malang, Indonesia

${ }^{c}$ Department of Public Administration, Faculty of Administrative Sciences, Universitas Brawijaya, Malang, Indonesia

${ }^{d}$ Faculty of Fisheries and Marine Science, Universitas Muslim Indonesia, Indonesia

\section{H R O N I C L E}

\begin{tabular}{l}
\hline Article history: \\
Received October 2, 2018 \\
Accepted November 202018 \\
Available online \\
November 202018 \\
\hline Keywords: \\
Strategic management \\
Supply chain \\
Service quality \\
Drinking water quality \\
Customer satisfaction \\
Company performance
\end{tabular}

\section{Introduction}

Access to water is one of the crucial issues worldwide. Demand for water has greatly increased with the increase in population. In the meantime, water accessibility and quality are likewise under growing stress from environmental change, climate change, land use decisions, energy scarcity, minerals processing and the requirements of the industry (Sabirah, 2013). It needs to discover better approaches to deal with utilization of fresh water for the future in order to have the capacity to serve developing populations. The world's 7.6 billion individuals spend around $4,500 \mathrm{~km}$ (4.5 teralitres) of freshwater yearly, generally $10 \%$ for household use, 70 percent for food purpose, and 20 percent for industry. This aggregate speaks to under five percent of that which is yearly accessible through precipitation. Therefore, while we confront regularly developing interest for water from one side, we confront 
extreme supply limitations. Research directed by the World Resource Industries has discovered that 41 percent of the total population or 2.3 billion individuals live in regions subject to regular water deficiencies. These are characterized as water stressed zones, having per capita supply of water is lower than $1,700 \mathrm{~m}^{3}(1,700,000$ liters') every year (World Wildlife Fund Website).

Therefore, to fulfil the increasing demand of water, better strategic supply chain activities are required. Strategic management and supply chain management (SCM) have interests in each other, yet there has been little trade between them. We investigate at common areas and recommend how insights of knowledge from each field can supplement as well as support the other. According to Ketchen Jr and Giunipero (2004), supply chain and strategic management are strongly associated with each other. Moreover, according to Kannan and Tan (2005), both strategic levels and operations level, supply chain and quality management are the significant part of operations strategy. Additionally, a study conducted by Schneller et al. (2006) in health care industry found significant positive relationship between supply chain and strategic management. Therefore, strategic management in supply chin can be used to as an instrument to fulfil the increasing need of water.

In the current study, service quality and drinking water quality are taken as strategic management instruments. The effects of service quality and drinking water quality are examined on SCM and customer satisfaction. Service quality has significant relationship with supply chain (Stanley \& Wisner, 2001) and supply chain has significant relationship with customer satisfaction (Heikkilä, 2002; Mahmood et al., 2016). An increase in service quality and drinking water quality also increases the SCM and customer satisfaction which automatically enhances the company performance.

Therefore, the objective of this study is to examine the role of supply chain strategic management in customer satisfaction and the performance of the water supply of the investigated company located in Makassar, Indonesia. The relationship between service quality, drinking water quality, SCM, customer satisfaction and company performance is shown in Fig. 1. Moreover, the study also tries

1. To examine the relationship between service quality and drinking water quality with SCM,

2. To examine the relationship between SCM and customer satisfaction,

3. To examine the relationship between customer satisfaction and company performance.

\section{Strategic Supply Chain Management}

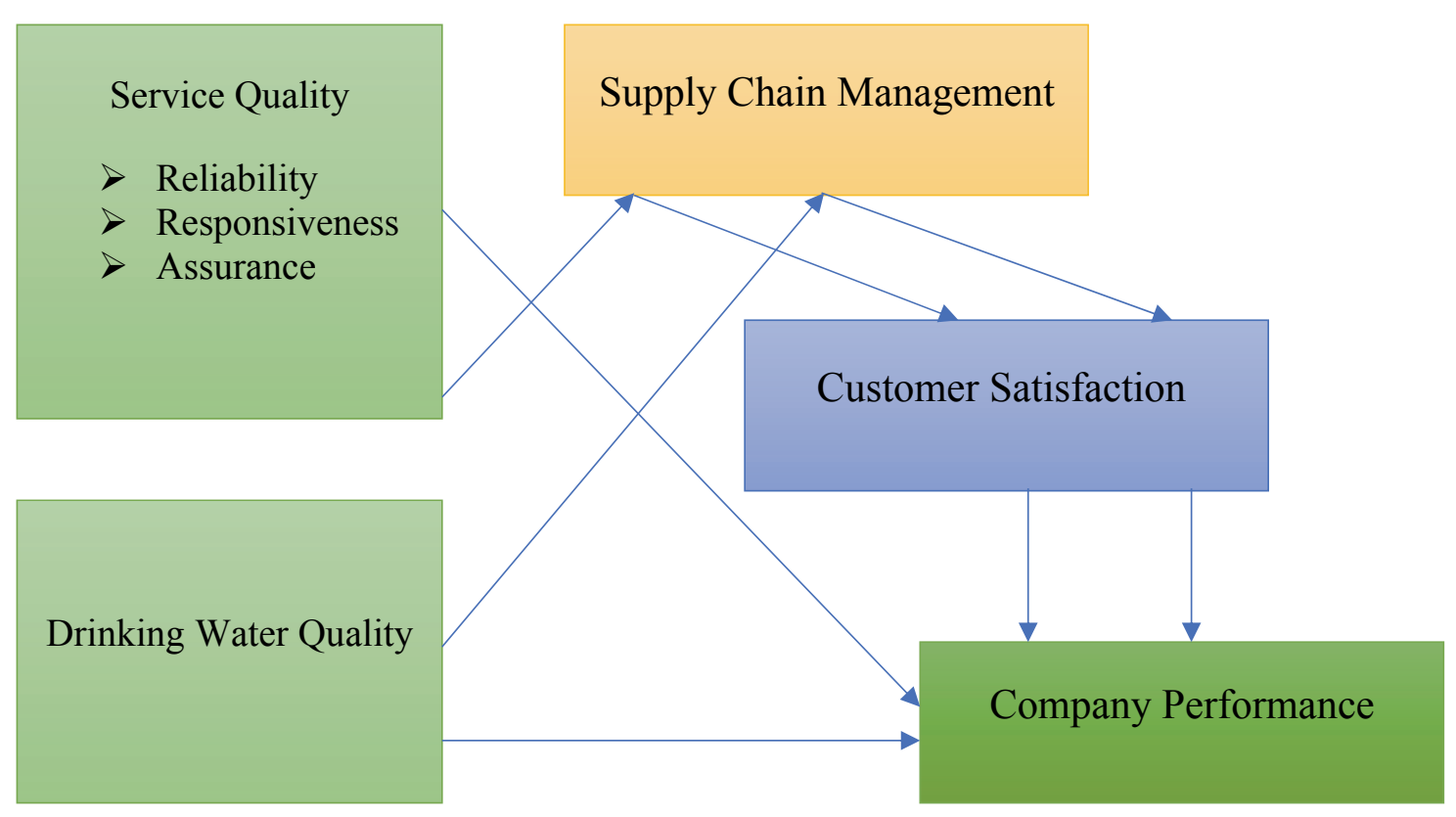

Fig. 1. Theoretical Framework of the study 


\section{Literature Review}

\subsection{Service quality, SCM, customer satisfaction and company performance}

The research studies of service quality have recognized various models by various researchers worldwide. Service quality can be described as clients' general impressions about organization's services (Johnston, 1995). Additionally, service quality is generally supposed to encounter and to surpass client's desires, as well as to incorporate a consistent enhancement procedure (Lloyd-Walker \& Ping Cheung, 1998). However, the SERVQUAL instrument (Parasuraman et al., 1988), a 22-item scale that estimates service quality along with various elements, in particular reliability, responsiveness and assurance, which is based on another work. According to Parasuraman et al. (1988), these measures including reliability, responsiveness and assurance are suitable to measure service quality. These service quality measures such as reliability, responsiveness and assurance play the key role in SCM and customer satisfaction. It also develops the awareness among the customers which shows positive effect on customer satisfaction (Basheer et al., 2015). It promotes water supply and enhances the level of customer satisfaction which has positive effect on company performance.

In conventional quality model (Parasuraman et al., 1988), quality should go to precede consumer loyalty. Perceived service quality has been characterized by a few researchers, the most acknowledged definitions clarifies perceived quality as the contrast among desires and real performance received by the customer from company (Gronroos, 1988). Quality can likewise be seen as a general judgment of the predominance or excellence of an item (Zeithaml, 1988). This general judgment of customer plays the key role on supply chain. As it has relationship with satisfaction of customer. Apart from customer satisfaction, it also has relationship with job satisfaction which plays an important role for the success of the operations of any company. In fact the job satisfaction is one of the important elements of every organization (Shah et al., 2018). Nowadays, accomplishing customer satisfaction is an essential objective for service related companies (Jones \& Sasser, 1995). Growth of both satisfaction as well as customer retention enhances profits, positive word-of-mouth, and lowers promoting consumptions. Ordinarily, service firms screen customer satisfaction by utilizing Likert-type scales that measure customer satisfaction level depending on the recent service experience (McDougall \& Levesque, 2000). It provides the link between quality of service and customer satisfaction which has relationship on supply chain. In the process that organizations create a quality item without giving great service, it is not ensuring the organization to hold competitive advantage for a longer period. Numerous researchers perceive that service quality has the ability to gain competitive advantage (Lewis, 1989; Moore, 1987). Service quality, customer satisfaction and customer perception of value have turned into the fundamental concerns of service organizations for the increasing competitive environment (Wang et al., 2004). Increases in quality also increases the supply chain of water supply firms which satisfies the customer and increases the company performance. Indeed there is a significant association between service quality, supply chain and customer satisfaction (Hennig et al., 1997; Seth et al., 2006) and customer satisfaction maintain positive effect on company performance (Lee \& How, 2018; Saeidi et al., 2015). Therefore, the following hypotheses are proposed:

$\mathbf{H}_{1}$ : There is a positive relationship between service quality and SCM.

$\mathbf{H}_{2}$ : There is a positive relationship between service quality and company performance.

$\mathbf{H}_{3}$ : There is a positive relationship between SCM and customer satisfaction.

$\mathbf{H}_{4}$ : There is a positive relationship between customer satisfaction and company performance.

\subsection{Drinking water quality, supply chain management, customer satisfaction and company} performance

Despite the fact that there is a composite index related to the water quality, a few countries have utilized or accumulated water quality information for the improvement of water quality indices. Generally water quality indices depend on normalizing, or institutionalizing, data parameter by parameters as per 
anticipated concentrations and some understanding of "good" versus "bad" concentrations (Sargaonkar \& Deshpande, 2003; Tsegaye et al., 2006). However, the current study focused on the relationship among water quality with supply chain, customer satisfaction and company performance. This study measured how water quality influences on SCM, customer satisfaction and company performance.

Drinking water quality is an important point of concern of all water supply companies (Edition, 2011; Organization, 2004; Aderinola et al., 2012; Galavi et al., 2012; Menbohan et al., 2013 Eid et al., 2014; Kessey \& Ampaabeng, 2014; Lohani et al., 2014; Tir et al., 2014; Tom \& Munemo, 2015; Kabir \& Aftab, 2017; Wang \& Huang, 2018; Jennifer \& Chi, 2018). Resolution of various issues with water quality is important link with customer satisfaction which enhances the SCM and company performance (Gray, 2008; Perez, 2014; Duru \& Chibo, 2014; Abiodun, 2014; Kaouther \& Besma, 2014; Chang'ach, 2018; Raza et al., 2018). Water supply is most crucial, as numerous water supply companies in urban emerging countries have to supply water intermittently between quickly growing demand as well as investment in supply chain infrastructure which increase water quality risks (Elala et al., 2011; Gabriel et al., 2015; Anwana \& Akpan, 2016; Haile et al., 2016; Ahmad et al., 2016; Wireko-Manu \& Amamoo, 2017). Thus, the enterprise risk handling and other stock return activities should also be considered in performance (Hameed et al., 2017; Maqbool et al., 2018). Therefore, demand of water is the most important issue, which can be handled with the help of SCM activities. Thus, there is a positive relationship between SCM and drinking water quality. Additionally, as it is discussed earlier, SCM has positive relationship with customer satisfaction (Chavez et al., 2016) and customer satisfaction has positive relationship with company performance (Mittal et al., 2017). Therefore, there is a significant link among these three elements, drinking water quality, SCM, and customer satisfaction. Moreover, SCM also has important role in company performance and increases the company performance through better management of operations (Li et al., 2006; Tan et al., 1998). Hence, SCM has the ability to enhance drinking water quality and company performance. All these three elements, namely; drinking water quality, SCM and company performance have positive relationship with each other. Thus, the following hypotheses are proposed by the current study;

H5: There is a positive relationship between drinking water quality and SCM.

$\mathbf{H}_{6}$ : There is a positive relationship between drinking water quality and company performance.

\section{Research Methodology}

The sampling technique that was employed in the current research study was convenience sampling technique. This was selected based on the time and cost limitations. The target population of this study was focused on employees of water supply companies located in region of Makassar, Indonesia. Pilot testing was carried out to test the scale developed in this study. For pilot testing, 100 questionnaires were distributed and 60 were returned and used for pilot testing. Results of the pilot testing show that all the scales were good enough to carry out the study. Moreover, questionnaire was provided to the experts and they were asked to highlight the necessary changes. Based on the experts' suggestions we have made some small changes. While doing the pilot study, it was found that few items were not good to retain. The items having factor loadings below 0.5 were deleted to increase the accuracy of scale. One item was deleted from customer satisfaction and one was deleted from company performance. After deleting the items having factor loading below 0.5, the scale of all the constructs have shown reasonable levels of reliability and validity. In this study, the sample size was selected based on the previous studies. To determine the sample size, total population of water supply companies in Makassar was required which was not available. Therefore, it was found from the literature that various studies used three hundred (300) sample size. Different studies also recommended that three hundred (300) sample size is appropriate to analyse the data. As it is demonstrated by Comrey and Lee (1992) that three hundred (300) sample size is suitable. Thus, the current study used three hundred (300) questionnaires to collect the data. Therefore, total three hundred (300) questionnaires were distributed among the employees of water supply companies of Makassar, Indonesia. All the questionnaires were distributed with the of convenience sampling technique. Moreover, a Likert scale was used to collect 
the data with 5-point Likert scale from disagree to agree. It is a good scale to collect the data as it increases the originality of the data as compared with other scales. Nevertheless, all the measures were adapted from previous studies.

\section{Analysis}

The current study used two-step procedure for assessing as well as reporting PLS-SEM outcomes (Henseler et al., 2009). It is described by Henseler et al. (2009) that the goodness-of-fit (GoF) index is not suitable for model validation as the GoF could not distinct the valid as well as invalid models; this indication was provided in a simulated research study that was carried out by utilization PLS path models (Hair et al., 2013). Thus, the present study adopted two-step method as suggested by Henseler et al. (2009) for the assessment of the results from the collected data of PLS-SEM path models. The two-step procedure comprises (1) assessment of outer model and (2) assessment of inner model. In case of current study, outer mode assessment is shown in Fig. 2.

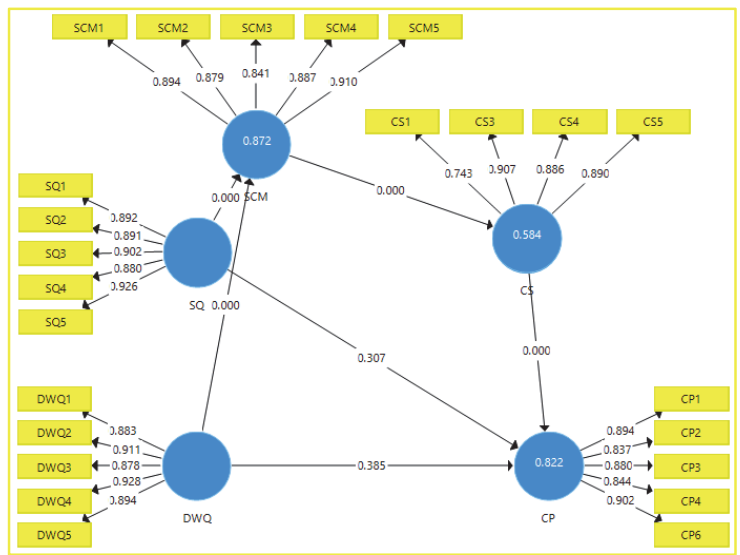

Fig. 2. Outer Model Assessment

According to the different studies such as Hair Jr et al. (2014), the factor loading should not be less than 0.7. In this study, factor loadings are shown in Fig. 2 and Table 1 and they are above 0.7 for all items. Factor loading above 0.7 shows better internal consistency of items.

\section{Table 1}

Factor Loadings

\begin{tabular}{|c|c|c|c|c|c|}
\hline & $\mathrm{CP}$ & $\mathrm{CS}$ & DWQ & SCM & SQ \\
\hline CP1 & 0.894 & & & & \\
\hline CP2 & 0.837 & & & & \\
\hline CP3 & 0.880 & & & & \\
\hline CP4 & 0.844 & & & & \\
\hline CP6 & 0.902 & & & & \\
\hline CS1 & & 0.743 & & & \\
\hline $\mathrm{CS} 3$ & & 0.907 & & & \\
\hline CS4 & & 0.886 & & & \\
\hline CS5 & & 0.890 & & & \\
\hline DWQ1 & & & 0.883 & & \\
\hline DWQ2 & & & 0.911 & & \\
\hline DWQ3 & & & 0.878 & & \\
\hline DWQ4 & & & 0.928 & & \\
\hline DWQ5 & & & 0.894 & & \\
\hline SCM1 & & & & 0.894 & \\
\hline SCM2 & & & & 0.879 & \\
\hline SCM3 & & & & 0.841 & \\
\hline SCM4 & & & & 0.887 & \\
\hline SCM5 & & & & 0.910 & \\
\hline SQ1 & & & & & 0.892 \\
\hline SQ2 & & & & & 0.891 \\
\hline SQ3 & & & & & 0.902 \\
\hline SQ4 & & & & & 0.880 \\
\hline SQ5 & & & & & 0.926 \\
\hline
\end{tabular}


It is clear from the literature, as evident by different studies such as Hair Jr et al. (2014); Reinartz et al. (2009) and Reinartz et al. (2009), the composite reliability should be above 0.7 and AVE should also be above 0.5 to attain the reasonable level of convergent validity. These values are shown in Table 2. Moreover, discriminant validity through cross loadings is shown in Table 3.

Table 2

Reliability and Validity

\begin{tabular}{lcccc}
\hline & $\boldsymbol{\alpha}$ & rho A & CR & AVE \\
\hline CP & 0.921 & 0.922 & 0.941 & 0.761 \\
CS & 0.879 & 0.882 & 0.918 & 0.738 \\
DWQ & 0.940 & 0.942 & 0.955 & 0.808 \\
SCM & 0.929 & 0.930 & 0.946 & 0.779 \\
SQ & 0.940 & 0.941 & 0.954 & 0.807 \\
\hline
\end{tabular}

Table 3

Cross loadings

\begin{tabular}{|c|c|c|c|c|c|}
\hline & $\mathrm{CP}$ & $\mathrm{CS}$ & DWQ & SCM & SQ \\
\hline CP1 & 0.894 & 0.818 & 0.596 & 0.639 & 0.609 \\
\hline CP2 & 0.837 & 0.748 & 0.508 & 0.552 & 0.551 \\
\hline CP3 & 0.880 & 0.777 & 0.556 & 0.622 & 0.554 \\
\hline CP4 & 0.844 & 0.789 & 0.507 & 0.577 & 0.525 \\
\hline CP6 & 0.902 & 0.816 & 0.649 & 0.682 & 0.643 \\
\hline CS1 & 0.573 & 0.943 & 0.84 & 0.822 & 0.808 \\
\hline CS3 & 0.857 & 0.907 & 0.564 & 0.591 & 0.618 \\
\hline CS4 & 0.858 & 0.886 & 0.582 & 0.621 & 0.596 \\
\hline CS5 & 0.808 & 0.890 & 0.561 & 0.6 & 0.577 \\
\hline DWQ1 & 0.597 & 0.656 & 0.883 & 0.804 & 0.838 \\
\hline DWQ2 & 0.607 & 0.707 & 0.911 & 0.855 & 0.839 \\
\hline DWQ3 & 0.514 & 0.592 & 0.878 & 0.772 & 0.761 \\
\hline DWQ4 & 0.627 & 0.694 & 0.928 & 0.845 & 0.805 \\
\hline DWQ5 & 0.557 & 0.66 & 0.894 & 0.834 & 0.809 \\
\hline SCM1 & 0.62 & 0.705 & 0.877 & 0.894 & 0.807 \\
\hline SCM2 & 0.617 & 0.644 & 0.794 & 0.879 & 0.766 \\
\hline SCM3 & 0.568 & 0.615 & 0.759 & 0.841 & 0.79 \\
\hline SCM4 & 0.649 & 0.687 & 0.8 & 0.887 & 0.8 \\
\hline SCM5 & 0.657 & 0.716 & 0.806 & 0.910 & 0.829 \\
\hline SQ1 & 0.568 & 0.671 & 0.827 & 0.821 & 0.892 \\
\hline SQ2 & 0.6 & 0.685 & 0.793 & 0.781 & 0.891 \\
\hline SQ3 & 0.557 & 0.657 & 0.81 & 0.813 & 0.902 \\
\hline SQ4 & 0.587 & 0.647 & 0.783 & 0.787 & 0.880 \\
\hline SQ5 & 0.657 & 0.723 & 0.838 & 0.859 & 0.926 \\
\hline
\end{tabular}

Inner model or structural model was assessed after outer or measurement model assessment. In this model, all the direct and indirect hypotheses were tested. To accept or reject the hypotheses, beta value, p-value and t-values were observed. The Fig. 3 shows the process of outer model or structural model assessment process. Table 4 shows all the results of direct effect to test the hypotheses.

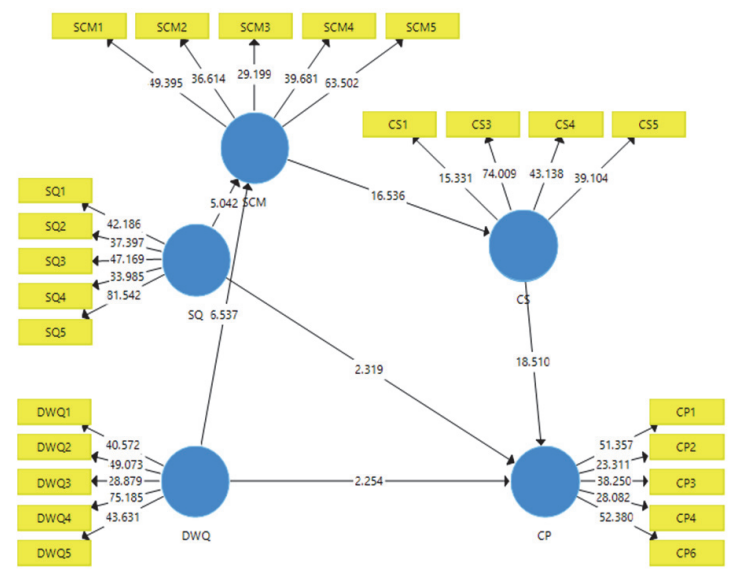

Fig. 3. Inner Model Assessment 
Table 4

Direct effect results

\begin{tabular}{lccccc}
\hline & $(\mathrm{O})$ & $(\mathrm{M})$ & $($ STDEV) & T Statistics & P Values \\
\hline $\mathrm{CS} \rightarrow \mathrm{CP}$ & 0.946 & 0.943 & 0.051 & 18.51 & 0.000 \\
$\mathrm{DWQ} \rightarrow \mathrm{CP}$ & 0.024 & 0.014 & 0.011 & 2.254 & 0.537 \\
$\mathrm{DWQ} \rightarrow \mathrm{SCM}$ & 0.533 & 0.531 & 0.082 & 16.536 & 0.000 \\
$\mathrm{SCM} \rightarrow \mathrm{CS}$ & 0.764 & 0.761 & 0.046 & 2.319 & 0.000 \\
$\mathrm{SQ} \rightarrow \mathrm{CP}$ & 0.03 & 0.036 & 0.013 & 5.042 & 0.025 \\
$\mathrm{SQ} \rightarrow \mathrm{SCM}$ & 0.424 & 0.427 & 0.084 & & 0.000 \\
\hline
\end{tabular}

From Table 4, it is clear that the t-value is above 1.96 for all relationships. It is also clear that the pvalue is below 0.05 . These values show that all the relationships are significant. Thus, all the direct effects are supported which accept these hypotheses. Additionally, it is also found that indirect effect is also significant in this study. It was found that SCM and CS are the mediating variable. As the results of mediation are shown in Table 5 and mediation effect is also shown in in Figs. (5-8).

Table 5

Mediation effect

\begin{tabular}{|c|c|c|c|c|c|}
\hline & $(\mathrm{O})$ & $(\mathrm{M})$ & (STDEV) & T Statistics & P Values \\
\hline $\mathrm{DWQ} \rightarrow \mathrm{SCM} \rightarrow \mathrm{CS} \rightarrow \mathrm{CP}$ & 0.385 & 0.381 & 0.065 & 5.945 & 0.000 \\
\hline $\mathrm{SQ} \rightarrow \mathrm{SCM} \rightarrow \mathrm{CS} \rightarrow \mathrm{CP}$ & 0.307 & 0.306 & 0.063 & 4.902 & 0.000 \\
\hline $\mathrm{DWQ} \rightarrow \mathrm{SCM} \rightarrow \mathrm{CS}$ & 0.407 & 0.404 & 0.068 & 5.984 & 0.000 \\
\hline $\mathrm{SQ} \rightarrow \mathrm{SCM} \rightarrow \mathrm{CS}$ & 0.324 & 0.325 & 0.066 & 4.899 & 0.000 \\
\hline
\end{tabular}

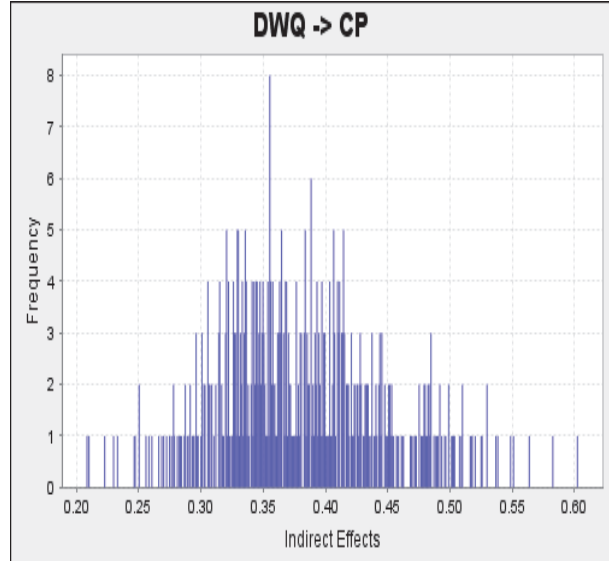

Fig. 5. Mediation effect of SCM and CS DWQ and CS

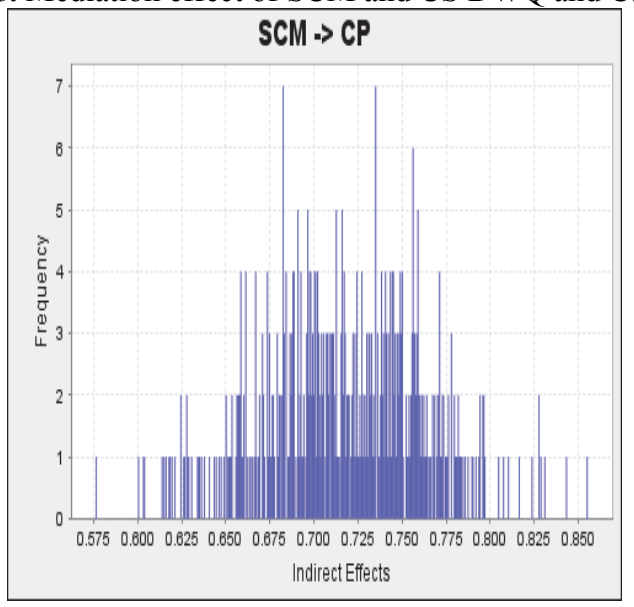

Fig. 7. Mediation effect of SCM between SQ and CS

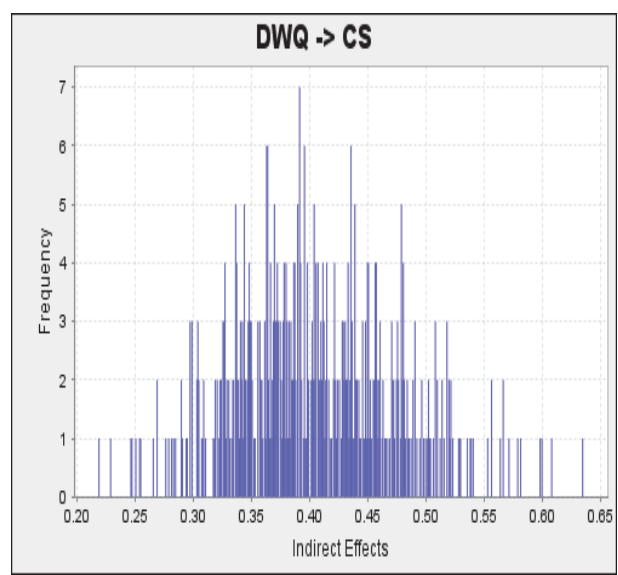

Fig. 6. Mediation effect of SCM between DWQ and CP

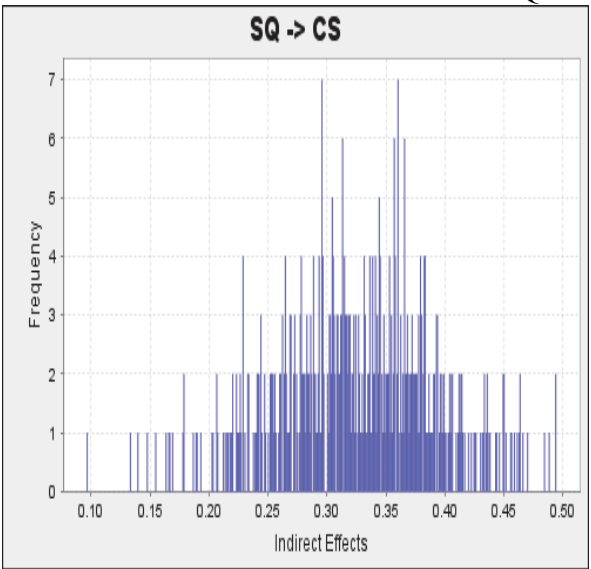

Fig. 8. Mediation effect of SCM and CS DWQ and CP 


\section{Findings}

The ultimate purpose of this study is to examine the effect of strategic management activities on SCM of water in water supply companies of Makassar, Indonesia. In this study, service quality and drinking water quality were taken as the strategic management tools. Effect of service quality and drinking water quality were examined on SCM. Moreover, the effects of SCM on customer satisfaction and water supply company performance were also examined. In this process, six hypotheses were formulated and tested with the help of structural equation modeling (SEM) technique by using partial least square (PLS). Data were collected from various employees of water supply companies in Makassar, Indonesia.

While analysing the hypotheses, it was found that service quality had significant positive relationship with SCM with t-value 5.042 and p-value 0.000 . There is a direct relationship between service quality and SCM. Increases in service quality had positive effect on SCM. Moreover, it was found that the relationship between drinking water quality and SCM was also significant with t-value 6.537 and pvalue 0.000 . Therefore, both service quality and drinking water quality had significant positive relationship with SCM. Increases in these two elements increases the supply chain among water supply companies. However, decreases in service quality and water quality decreases the quality of the supply chain. Furthermore, SCM has direct relationship with customer satisfaction. Better supply chain practices in water supply companies increases the satisfaction level among the people of Makassar city. As the relationship between SCM and customer satisfaction was found positive and significant with tvalue 16.536 , p-value 0.000 and beta 0.764 . Nevertheless, customer satisfaction increases the water supply performance. The relationship between customer satisfaction and company performance was found significant with t-value 18.51 and beta value 0.946 . These findings are in line with other studies such as Williams and Naumann (2011) and Al-Hawari and Ward (2006). These studies also found that customer satisfaction increases the company performance. Finally, it was found that SCM and customer satisfaction are the mediating variable between services quality and company performance. Moreover, SCM and customer satisfaction also was also a mediating variable between drinking water quality and company performance. Both SCM and customer satisfaction increase the positive effect of service quality and drinking water quality on water supply company's performance.

\section{Conclusion}

While analysing the data and summing up the findings, it was found that water supply companies of Makassar needs better supply chain activities to boost performance. Better supply chain implementation is the key to customer satisfaction and company performance. Better water supply chain has the ability to enhance customer intention to stick with company which has significant influence on performance. It was found that strategic management activities such as service quality and drinking water quality can increase the SCM. Good drinking water quality as compared with the other water supply companies and better-quality promote customer satisfaction level, SCM and company performance. Both SCM and customer satisfaction enhance the positive effect on service quality and drinking water quality on water supply company's performance. Therefore, Makassar water supply companies must insurance good quality services and good quality drinking water to boost their performance level and profitability. Therefore, this study is beneficial for water supply companies to help while making the strategies to enhance performance.

\section{References}

Abiodun, B. Y. (2014). The prospects of accounting and economic systems in the era of global knowledge economy. The Economics and Finance Letters, 1(2), 9-14.

Aderinola, O. J., Kusemiju, V., \& Clarke, E. O. (2012). Trace metal distribution in surface water, sediment, and tissues of freshwater catfish (Clarias. gariepinus), from Oke-Afa canal, Lagos Nigeria. International Journal of Geography and Geology, 1(1), 10. 
Ahmad, I., Das, T. T., Yasin, M., \& Hossain, M. A. (2016). Study on biochemical compounds, antioxidant activity and organoleptic taste of some spice tea. Agriculture and Food Sciences Research, 3(2), 53-58.

Al-Hawari, M., \& Ward, T. (2006). The effect of automated service quality on Australian banks' financial performance and the mediating role of customer satisfaction. Marketing Intelligence \& Planning, 24(2), 127-147.

Anwana, E. O., \& Akpan, B. (2016). Power sector reforms and electricity supply growth in Nigeria. Asian Journal of Economics and Empirical Research, 3(1), 94-102.

Basheer, M. F., Hussain, T., Hussan, S. G., \& Javed, M. (2015). Impact of customer awareness, competition and interest rate on growth of Islamic banking in Pakistan. International Journal of Scientific \& Technology Research, 4(8), 33-40.

Chang'ach, J. K. (2018). An historical trajectory of the economic transformation of the southern Keiyo community in Kenya. Global Journal of Social Sciences Studies, 4(2), 52-69.

Chavez, R., Yu, W., Feng, M., \& Wiengarten, F. (2016). The effect of customer-centric green supply chain management on operational performance and customer satisfaction. Business Strategy and the Environment, 25(3), 205-220.

Comrey, A., \& Lee, H. (1992). A First Course in Factor Analysis (2nd edn.) Lawrence Earlbaum Associates. Publishers: Hillsdale, New Jersey.

Duru, P. N., \& Chibo, C. N. (2014). Flooding in Imo state Nigeria: The socio-economic implication for sustainable development. Humanities and Social Sciences Letters, 2(3), 129-140.

Edition, F. (2011). Guidelines for drinking-water quality. WHO chronicle, 38(4), 104-108.

Eid, A. R., Mohamed, M. H., Pipars, S. K., \& Bakry, B. A. (2014). Impact of laser land leveling on water productivity of wheat under deficit irrigation conditions. Current Research in Agricultural Sciences, 1(2), 53-64.

Elala, D., Labhasetwar, P., \& Tyrrel, S. F. (2011). Deterioration in water quality from supply chain to household and appropriate storage in the context of intermittent water supplies. Water Science and Technology: Water Supply, 11(4), 400-408.

F. Hair Jr, J., Sarstedt, M., Hopkins, L., \& G. Kuppelwieser, V. (2014). Partial least squares structural equation modeling (PLS-SEM) An emerging tool in business research. European Business Review, 26(2), 106-121.

Gabriel, O. M., Onyukwu Onyukwu, E., \& Ikpeze Nnaemeka, I. (2015). Households' perception of factors influencing agricultural productivity in ogoni community: An ordinal logit approach. Asian Journal of Economics and Empirical Research, 2(2), 76-82.

Galavi, M., Bazrafshan, E., Mostafapor, F. C., \& Pakzadtoochaei, S. (2012). A comparative study of physical and chemical parameters in Sistan and Baluchistan university wastewater and its re-use of wastewater. International Journal of Sustainable Energy and Environmental Research, 1(1), 7-12.

Gray, N. F. (2008). Drinking water quality: problems and solutions. Cambridge University Press.

Gronroos, C. (1988). Service quality: The six criteria of good perceived service. Review of Business, 9(3), 10.

Haile, A., Geribo, M., \& Kinfe, E. (2016). Evaluation of porridge made from composite flour of orangefleshed sweet potato and Enset (Bulla) flours. Agriculture and Food Sciences Research, 3(1), $37-$ 44.

Hair, J. F., Ringle, C. M., \& Sarstedt, M. (2013). Partial least squares structural equation modelling. Rigorous applications, better results and higher acceptance.

Hameed, W.-U., Hashmi, F., Ali, M., \& Arif, M. (2017). Enterprise risk management (ERM) system: Implementation problem and role of audit effectiveness in Malaysian firms. Asian Journal of Multidisciplinary Studies, 5, 11. 
Heikkilä, J. (2002). From supply to demand chain management: efficiency and customer satisfaction. Journal of Operations Management, 20(6), 747-767.

Hennig-Thurau, T., \& Klee, A. (1997). The impact of customer satisfaction and relationship quality on customer retention: A critical reassessment and model development. Psychology \& Marketing, 14(8), 737-764.

Henseler, J., Ringle, C. M., \& Sinkovics, R. R. (2009). The use of partial least squares path modeling in international marketing New challenges to international marketing (pp. 277-319). Emerald Group Publishing Limited.

Jennifer, C. H. I., \& Chi, Y. N. (2018). Profiling saltwater recreational anglers toward the threats of marine environment. International Journal of Management and Sustainability, 7(2), 72-82.

Johnston, R. (1995). The determinants of service quality: satisfiers and dissatisfiers. International Journal of Service Industry Management, 6(5), 53-71.

Jones, T. O., \& Sasser, W. E. (1995). Why satisfied customers defect. Harvard Business Review, 73(6), 88-\&.

Kabir, K. H., \& Aftab, S. (2017). Exploring management strategies for freshwater wetland: Policy options for southwest coastal region in Bangladesh. Asian Development Policy Review, 5(2), 70-80.

Kannan, V. R., \& Tan, K. C. (2005). Just in time, total quality management, and supply chain management: understanding their linkages and impact on business performance. Omega, 33(2), 153 162.

Kaouther, A., \& Besma, T. (2014). Study of the relationship between economic growth and inflation: Application to the countries of the south side of the Mediterranean: A panel data approach. Journal of Social Economics Research, 1(8), 180-190.

Kessey, K. D., \& Ampaabeng, I. (2014). Management in public utility companies in Ghana: an appraisal of Ghana water company limited. International Journal of Management and Sustainability, 3(8), 500.

Ketchen Jr, D. J., \& Giunipero, L. C. (2004). The intersection of strategic management and supply chain management. Industrial Marketing Management, 33(1), 51-56.

Lee, C. G., \& How, S.-M. (2018). Long-run causality between customer satisfaction and financial performance: the case of Marriott. Current Issues in Tourism, 1-6.

Lewis, B. R. (1989). Quality in the service sector: a review. International Journal of Bank Marketing, 7(5), 4-12.

Li, S., Ragu-Nathan, B., Ragu-Nathan, T., \& Rao, S. S. (2006). The impact of supply chain management practices on competitive advantage and organizational performance. Omega, 34(2), 107-124.

Lloyd-Walker, B., \& Ping Cheung, Y. (1998). IT to support service quality excellence in the Australian banking industry. Managing Service Quality: An International Journal, 8(5), 350-358.

Lohani, T. K., Barik, P., Patnaik, B. C., \& Mansingh, S. K. (2014). Micro level geo-resistivity survey through VES test for groundwater feasibility study and selection of bore well sites in Pipili Block of Puri. Review of Environment and Earth Sciences, 1(2), 37-45.

Mahmood, A., Hussan, S. G., Sarfraz, M., Abdullah, M. I., \& Basheer, M. F. (2016). Rewards satisfaction, perception about social status and commitment of nurses in Pakistan. European Online Journal of Natural and Social Sciences, 5(4), 1049-1061.

Maqbool, N., Hameed, W., \& Habib, M. (2018). Impact of political influences on stock returns. International Journal of Multidisciplinary Scientific Publication (IJMSP), 1(1).

McDougall, G. H., \& Levesque, T. (2000). Customer satisfaction with services: putting perceived value into the equation. Journal of Services Marketing, 14(5), 392-410.

Menbohan, F., Tchakonte, S., \& Njiné, T. (2013). Water quality assessment using benthic macroinvertebrates in a periurban stream (Cameroon). International Journal of Biotechnology, 2(5), 91-104. 
Mittal, V., Han, K., Lee, J.-Y., Im, B., \& Sridhar, S. (2017). Attribute-Level Satisfaction, Overall Customer Satisfaction, and Performance Outcomes in Business-to-Business Firms.

Moore, T. (1987). A preliminary study of the effects of drainage and harvesting on water quality in Ombrotrophic bogs near Septiles, Quebec. Journal of the American Water Resources Association, 23(5), 785-791.

Organization, W. H. (2004). Guidelines for drinking-water quality: recommendations (Vol. 1): World Health Organization.

Parasuraman, A., Zeithaml, V. A., \& Berry, L. L. (1988). Servqual: A multiple-item scale for measuring consumer perc. Journal of retailing, 64(1), 12.

Perez, L. V. (2014). Saving Natural Resources: The Exemple of Balearic Industry/Ahorro De Recursos Naturales: El Ejemplo De La Industria Balear. Journal of Tourism Management Research, 1(2), 8391.

Raza, H., Mohiuddin, Z. A., Zaidi, S. S. Z., \& Osama, A. (2018). CPEC: Pakistan-China Cordial TiesA Boost to Pakistan's Economy. Journal of Accounting, Business and Finance Research, 2(1), 1-6.

Reinartz, W., Haenlein, M., \& Henseler, J. (2009). An empirical comparison of the efficacy of covariance-based and variance-based SEM. International Journal of Research in Marketing, 26(4), 332-344.

Sabirah, S. (2013). Domestic water demand: A case study in Kluang, Johor. Universiti Utara Malaysia. Saeidi, S. P., Sofian, S., Saeidi, P., Saeidi, S. P., \& Saaeidi, S. A. (2015). How does corporate social responsibility contribute to firm financial performance? The mediating role of competitive advantage, reputation, and customer satisfaction. Journal of Business Research, 68(2), 341-350.

Sargaonkar, A., \& Deshpande, V. (2003). Development of an overall index of pollution for surface water based on a general classification scheme in Indian context. Environmental Monitoring and Assessment, 89(1), 43-67.

Schneller, E. S., Smeltzer, L. R., \& Burns, L. R. (2006). Strategic management of the health care supply chain.

Seth, N., Deshmukh, S., \& Vrat, P. (2006). A conceptual model for quality of service in the supply chain. International Journal of Physical Distribution \& Logistics Management, 36(7), 547-575.

Shah, S. M. M., Ali, R., Dahri, A. S., Ahmed, N., \& Brohi, Z. A. M. (2018). Determinants of job satisfaction among nurses: Evidence from south Asian perspective. Journal of Academic Research in Business and Social Sciences, 8(5), 19-26.

Stanley, L. L., \& Wisner, J. D. (2001). Service quality along the supply chain: implications for purchasing. Journal of operations management, 19(3), 287-306.

Tan, K. C., Kannan, V. R., \& Handfield, R. B. (1998). Supply chain management: supplier performance and firm performance. Journal of Supply Chain Management, 34(3), 2.

Tir, N. A., Momeni, F., \& Boboevich, G. T. (2014). Consideration the effects of water sector investment on economic growth in Iran. International Journal of Sustainable Development \& World Policy, 3(5), 132-137.

Tom, T., \& Munemo, E. (2015). Republic of Zimbabwe national water policy: a desk review of the gaps between the policy and its implementation. International Journal of Public Policy and Administration Research, 2(3), 60-72.

Tsegaye, T., Sheppard, D., Islam, K., Tadesse, W., Atalay, A., \& Marzen, L. (2006). Development of chemical index as a measure of in-stream water quality in response to land-use and land cover changes. Water, Air, and Soil Pollution, 174(1-4), 161-179.

Wang, D. H. M., \& Huang, C. Y. (2018). Construction and Application of Water Resource Accounting Information System in Taiwan. International Journal of Business, Economics and Management, $5(1), 1-15$. 
Wang, Y., Lo, H.-P., \& Yang, Y. (2004). An integrated framework for service quality, customer value, satisfaction: Evidence from China's telecommunication industry. Information Systems Frontiers, 6(4), 325-340.

Williams, P., \& Naumann, E. (2011). Customer satisfaction and business performance: a firm-level analysis. Journal of Services Marketing, 25(1), 20-32.

Wireko-Manu, F. D., \& Amamoo, C. (2017). Comparative studies on proximate and some mineral composition of selected local rice varieties and imported rice brands in Ghana. Agriculture and Food Sciences Research, 4(1), 1-7.

Zeithaml, V. A. (1988). Consumer perceptions of price, quality, and value: a means-end model and synthesis of evidence. The Journal of Marketing, 52(3), 2-22.

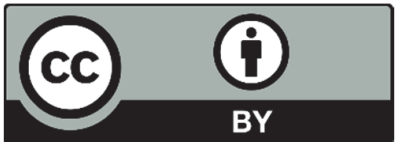

(C) 2019 by the authors; licensee Growing Science, Canada. This is an open access article distributed under the terms and conditions of the Creative Commons Attribution (CC-BY) license (http://creativecommons.org/licenses/by/4.0/). 